ISSN: 2362-1303 (Paper) | elSSN: 2362-1311(Online)

JOURNAL OF ADVANCED ACADEMIC RESEARCH (JAAR)

$\operatorname{Jan} 2016$

A Pregnant Women's Group: Page22

\title{
A Pregnant Women's Group: Its Effects on Maternal and Neonatal Health Care Services among Disadvantaged Community in Makawanpur, Nepal
}

\author{
Bhagawan Das Shrestha, Master in Public Health, \\ Ph. D. scholar, Mewar University \\ Technical Officer on Reproductive Health and Family Planning, \\ Department of Health Protection and Promotion, \\ World Health Organization, Regional Office for Eastern Mediterranean, \\ Cairo, Egypt. \\ Email: bdshrestha3@ gmail.com or shresthabh@who.int
}


ISSN: 2362-1303 (Paper) | elSSN: 2362-1311(Online)

JOURNAL OF ADVANCED ACADEMIC RESEARCH (JAAR)

$\operatorname{Jan} 2016$

A Pregnant Women's Group: Page23

\begin{abstract}
In Nepal, the utilization of maternal, newborn and child health (MNCH) care services exhibit big gaps between rich and poor, for instance poorest quintile is at $10.7 \%$ skill births attendant services but richest at $81.5 \%$, despite the services being free of cost. Pregnant women group (PWG) approach was initiated to address MNCH inequities prevailing in the disadvantaged community. The PWG is a socially cohesive peer support group of 8-15 pregnant women and postnatal mothers who meet monthly for participatory teaching and learning sessions on MNCH cares and semi-annual publicly group commitment meetings. At the meetings, husbands and mothers-in-law verbally commit to support their pregnant wives and daughters-in-law in present of pregnant women. Local health staff also commits to provide those services. Retrospective cohort study was undertaken in which 449 randomly selected recently delivered women who were members of $P W G$ in last pregnancy and next 449 non-members to $P W G$ from same villages of Makwanpur were introduced the structured questionnaires between March and April 2015. The results indicated that the increase in the utilization of $M N C H$ care services was statistically significant $(P<0.0001$ for all indicators) among women who were $P W G$ members than those who were not. Despite the fact that the average age, educational status, parity, ethnicity, location and access to health services were constant. Pregnant women's group approach increases the utilization of MNCH care services for disadvantaged community in Makwanpur, Nepal. Thus, the PWG approach can be a strategy to reduce the inequity MNCH care services coverage in developing countries.
\end{abstract}

\title{
Key Words:
}

Disadvantaged community, inequality health care service, maternal and newborn mortality, pregnant women's group, utilization of health care service 
A Pregnant Women's Group: Page24

\section{INTRODUCTION}

The maternal mortality ratio (MMR) in developing regions is still considerably high and stands at 239 per 100,000 live births as of 2015, which is roughly 20 times higher than that of developed regions. Regions such as Oceania, South Asia and South Eastern Asia have average MMR of 187, 176 and 110 respectively. Nepal which lies in the South Asia has MMR of 258 per 100,000 live births (WHO, 2015).

Further still under-five mortality rate (U5MR) in South Asian region is high and stands at 51 deaths per 1,000 live births as of 2015. This implies that three in 10 global under-five deaths occur in Southern Asia. Nepal has U5MR of 36 and neonatal mortality rate of 22 deaths per 1,000 live births as of 2015 (UNICEF 2015). The child deaths are caused by diseases that are readily preventable or treatable with proven, cost-effective and quality-delivered interventions. The interventions include active management of third stage of labour, use of misoprostol, community based newborn care programme, naval care with chlorhexidine. The Government of Nepal is implementing these interventions free of cost at all government health facilities. However, despite the availability of the services, the rate of access and utilization of the services especially among the needy and vulnerable is very low partly because the communities still think such services are not important. Then there is a challenge of how to make those services accessible and utilizable by the needy people and of how to reduce on the maternal and newborn deaths. Studies have shown that there is a big gap in the utilization of health care services between rich and poor, literate and illiterate in Nepal despite those services being free of cost. For example: studies showed that the poorest quintile had a $10.7 \%$ SBA delivery rate; whereas the wealthiest quintile had a rate of $81.5 \%$, despite SBA services being free of cost at government health facilities (Ministry of Health and Population Nepal, New Era, and ICF International INC. 2012). There is a need of innovative processes and strategies to increase the utilization of locally available maternal and newborn health services. As such the government of Nepal initiated, the pregnant women group (PWG) approach to increase the utilization of health care services especially among disadvantaged communities in six districts of Nepal, namely Sunsari, Rautahat, Bara, Parsa, Makawanpur and Banke. As a result more than 1,200 PWGs have been established from 2003 to 2013. Therefore my research focused on PWG approach and how it increases the utilization of maternal and newborn health services by mostly needy communities.

A pregnant women's group is a socially cohesive peer support group of 8-15 pregnant women and postnatal mothers who live in the same ward and meet monthly. The integrated PWG approach helps pregnant women self-monitor their utilization of maternal and newborn health services, while positive peer pressure within the group acts as motivation for behavior change. The groups not only empower women to advocate to husbands and in-laws on the necessity of visiting health service providers but also put pressure on local health providers to ensure quality and timely health services are provided. The pregnant women and postnatal mothers self-monitor the utilization of antenatal and postnatal services along with birth preparedness plan and newborn birth registration. They monitor the utilization of services by using a social behavioural mapping mat in which they paste different colored marks "Tika" (Shrestha BD 2009). The PWG approach includes two activities (1)monthly health education sessions for PWG by using a behavioural mapping mat for self-monitoring facilitated by female community health volunteers (FCHVs), and (2)semi-annual publicly group commitments meetings. At the meetings, husbands and 
ISSN: 2362-1303 (Paper) | elSSN: 2362-1311(Online)

JOURNAL OF ADVANCED ACADEMIC RESEARCH (JAAR)

Jan 2016

A Pregnant Women's Group: Page25

mothers-in-law verbally commit to support their pregnant wives and daughters-in-law in front of pregnant women, FCHVs, and local health staff also commits to provide those services.

The conceptual framework below shows how the pregnant women's groups approach increases the utilization of maternal newborn and child health care services.

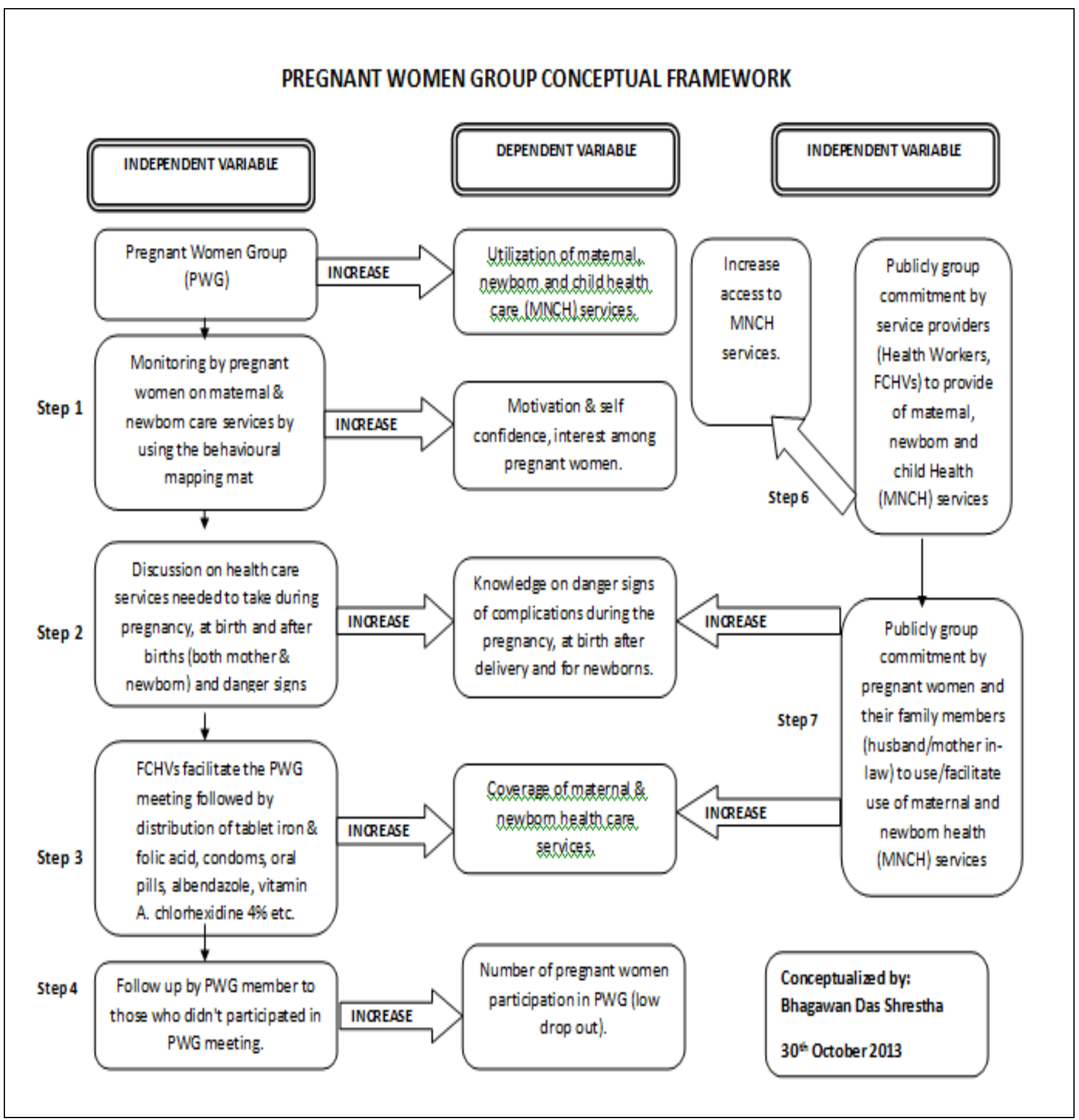

Vol. 3. No. I

www.phdcentre.edu.np 
The objectives of the study were:

1. To examine the coverage of maternal and newborn health services between pregnant women group (PWG) members and non-members in a disadvantaged community of Makwanpur hill district;

2. To draw the epidemiological conclusion whether the pregnant women group (PWG) increases the utilization of maternal and newborn health services in hill district; and

3. To assess the self-monitoring behavioural mapping mat used in pregnant women group (PWG) as an appropriate health education method for illiterate disadvantaged women groups.

The following are the research questions.

Question 1: Does the pregnant women group approach affect the coverage of maternal and newborn health services in disadvantaged community?

Question 2: Does the pregnant women group approach affect the coverage of maternal and newborn health services in the hilly areas with limited transportation facilities?

Question 3: Is the self-monitoring behavioural mapping mat media used in pregnant women group (PWG)'s monthly meeting useful to provide health education for the disadvantaged pregnant women?

\section{Research gap:}

The meta-analysis of Bangladesh, Malawi, India and Nepal (Audrey Prost, The lancet 18 May 2013) of all trials showed that exposure to women's groups was associated with a $37 \%$ reduction in maternal mortality (odds ratio $0.63,95 \%$ CI $0.32-0.94$ ), a $23 \%$ reduction in neonatal mortality $(0.77$, $0.65-0.90)$, and a $9 \%$ non-significant reduction in stillbirths $(0.91,0.79-1.03)$, with high heterogeneity for maternal ( $\mathrm{I} 2=58.8 \%, \mathrm{p}=0.024)$ and neonatal results $(\mathrm{I} 2=64.7 \%, \mathrm{p}=0.009)$. In the same way, metaanalysis a subgroup analysis of the four studies in which at least $30 \%$ of pregnant women participated in groups showed a $55 \%$ reduction in maternal mortality $(0.45,0.17-0.73)$ and a $33 \%$ reduction in neonatal mortality $(0.67,0.59-0.74)$. The Bara pregnant women group (PWG) study also demonstrated with high precision that PWG members have reduced risk (about 50\% less) of dying during pregnancy, childbirth and puerperium as compared to the non-PWG members. The findings further indicated that children of PWG members lower risk of dying during perinatal and infancy periods in Bara Nepal.

Dipty Nawal, The Lancet, 17 June 2013 reported that the socio economic inequality in utilization of maternal and newborn child health services showed that health inequality is more concentrated on economically poor people, but the strength of the association varies between countries. Results of decomposition analyses indicate that the critical factor contributing to disparity in the number of antenatal care visits is the poor economic status of the household (41\% [95\% CI 37.5-44.5] in Ethiopia, 31\% [2834] in Nepal, and 68\% [64-72] in Zimbabwe. However, place of residence was the major contributor for delivery outside of a health-care setting (10\% [7.3-12.7] in Bangladesh, 58\% [50.2-66.4] in Ethiopia, 
A Pregnant Women's Group: Page27

$20 \%$ [16.4-23.7] in Nepal, 34\% [30-38]) in Zimbabwe. For postnatal care, the absolute level of association is greater with birth order $3+(\beta=0 \cdot 1748)$ in Nepal.

Though there is a study of participatory learning in women group (women group with one third of pregnant women) and its effects on maternal and newborn care services, there is research gap that there is no study on the pregnant women group and its effect on maternal and newborn care services in disadvantaged community in a hill district of Nepal. A similar study on PWG was conducted in Bara in the low and flat lands of Terai with clustered households with facilities of transportations which were different in context from the current study. This study was done in a disadvantaged community of a hill district of Nepal where there are scattered households which are far from the local health facilities with limited transportation facilities. Therefore this study assessed the utilization of maternal and newborn health services in hill district of Makwanpur among the pregnant women group members and pregnant women who are not members of PWG. In Makwanpur, there are 170 pregnant women groups as of June 2013.

\section{METHOD}

\section{Study Variables:}

Independent variable: The pregnant women group (PWG) (cause)

Dependent variable: The utilization of maternal and newborn health services (coverage) in disadvantaged community in the hill district (effects)

Type of Study

This is an observational analytical investigation. This study is a retrospective cohort study as all the events - exposure (exposed to Pregnant Women Group - PWG), latent period (a village where there was a pregnant women group since minimum of last one year), and subsequent outcome (e.g. Increase/decrease in utilization maternal, newborn and child health $(\mathrm{MNCH})$ care services like coverage of antenatal care visits in last pregnancy) have already occurred in the past. We merely collected the data about women exposed to PWG and not exposed to PWG, then compared the data of the exposed and nonexposed groups and established the association between $\mathrm{MNCH}$ care service coverage and PWG approach.

\section{Study Site and its Justification}

The study site was Makwanpur district in Nepal. The population of the study was 29 village development committees (VDCs) of Makwanpur Districts where there were pregnant women groups since at least one year. The appropriate number of sample was selected from the population of the study areas using census method.

In Nepal, six districts namely Sunsari, Rautahat, Bara, Parsa, Makawanpur and Banke have more than 1,200 pregnant women groups (PWGs). Among six districts, Makwanpur is the only hilly district. Makwanpur has the lowest institutional delivery of $23 \%$ among the six districts with Banke district the highest at 73\% (District Health Office Makwanpur, 2012). 
ISSN: 2362-1303 (Paper) | elSSN: 2362-1311(Online)

JOURNAL OF ADVANCED ACADEMIC RESEARCH (JAAR)

$\operatorname{Jan} 2016$

A Pregnant Women's Group: Page28

$\underline{\text { Study Population }}$

Recently delivered (live or still births ) women (in the last one year) who were member of pregnant women group during their last pregnancy, for the exposed group and who are not the members of pregnant women group, for the non-exposed group from 29 village development committees of Makwanpur district of Nepal, where there were 130 pregnant women groups.

\section{Study Unit}

The study unit was recently delivered women (live or still births) in last one year.

Sampling Methods / Techniques

The sampling procedure was as follows:

Step 1: Listed all 130 pregnant women groups which were formed one year before with their addresses, ward numbers and name of village development committees (VDC);

Step 2: Met with concerned Health Facility In-charge and Female Community Health Volunteers (FCHVs) and briefed on the study objectives;

Step 3: FCHVs called all the mothers (average 6 pregnancies per ward / per year in Makwanpur district) who delivered child (live or still) in last one year in her wards. The immunization clinic day in the ward (if the ward had) was utilized for this step;

Step 4: Asked the mothers, who were the members of the PWG during their last pregnancy and verified with the register of the PWG with concerned FCHVs;

Step 5: Asked the women, who were members of the PWG in their last pregnancy how many times had they participated in the PWG meeting.

Step 6: All the mothers (census) whose answers were that they had participated in PWG three or more times were interviewed as an exposed group. The mothers who had participated less than 3 times in the PWG were excluded in the survey;

Step 7: The remaining mothers who had not participated in any PWG meeting in their last pregnancy were selected randomly for the interview for a non-exposed group. The number of the non-exposed group interviewed was equal to the number of exposed group interviewed in each VDC;

Step 8: If in case there were lesser number of mothers for the non-exposed group than for the exposed group, we took the remaining sample from the nearby ward of the same VDC. So sample numbers for the exposed and non-exposed groups were equal in the each VDC; and

Step 9: The same process was followed for other 130 PWGs in 29 VDCs of the district..

Sample size (with justification)

Vol. 3. No. I

www.phdcentre.edu.np 
The total sample size was 846 . The estimated sample size was 423 of recently delivered women who delivered live or still births in the last one year who were members of pregnant women group during the last pregnancy for the exposed group and next 423 who were not the member of pregnant women groups for the non-exposed group.

To conduct the household survey statistically representative, the mother who delivered live or still births (both who were pregnant women group member and not member during the last pregnancy) were from all the Village Development Committee where there were pregnant women groups at least one year back. To determine the total sample size, the reference prevalence ( $\mathrm{p}$ ) of the national prevalence of maternal and newborn health services coverage was taken to be $50 \%$. Using $5 \%$ as the allowable error, and $10 \%$ as non-response, the total sample size was 423 mothers who delivered live or still births in the last one year as per the formula $\mathrm{Z}^{2}$ x p x (1-p) x design effect $\times(1+n r) / \mathrm{d}^{2}$.

Calculation of the sample size was as follows:

Sample size calculation formula $\quad y=\underline{Z^{2} \times p \times(1-p) \times \text { design effect } \times(1+n r)}$

\section{$d^{2}$}

Proportion of maternal and newborn health services $(\mathrm{p})=50 \%(0.5)$

Allowable error $(\mathrm{d})=5 \%(0.05)$

No response $(\mathrm{nr})=10 \%(0.1)$

Where:

$\mathrm{D}=$ Sample size

$\mathrm{Z}^{2}\left(1-\frac{\alpha}{2}\right)=5 \%$ level of significance $(1.96)$

$\mathrm{P}=$ Proportion of maternal and newborn health services coverage $(0.5)$

Design effect $=$ Design effect is set to minimize sampling variability caused by cluster sampling, but in this study census and simple random sampling so design effect will one (1).

$\mathrm{Nr}=$ No response rate; it is assumed $10 \%(0.1)$ will not answer

$\mathrm{d}=$ Allowable error (0.05).

The equation for deriving the sample size is given as below.

$$
\begin{aligned}
& y=\underline{Z^{2} \times p \times(1-p) \times \text { design effect } \times(1+n r)} \\
& d^{2} \\
& \text { or } y=\underline{(1.96)^{2} \times 0.5 \times 0.5 \times 1 \times(1+0.1)}
\end{aligned}
$$


ISSN: 2362-1303 (Paper) | elSSN: 2362-1311(Online)

JOURNAL OF ADVANCED ACADEMIC RESEARCH (JAAR)

$\operatorname{Jan} 2016$

A Pregnant Women's Group: Page30

$0.05^{2}$

or $\mathrm{y}=\underline{(3.8416 \times 0.25 \times 1 \times 1.1)}$

0.0025

or $\eta=\underline{1.05644}$

0.0025

$\therefore \mathrm{y}=422.576=\mathbf{4 2 3}$

Criteria for Sample Selection

For the exposed group:

1. A recently delivered woman who delivered live or still births in the last one year who was the members of pregnant women group during her last pregnancy;

2. The woman, who had participated in the pregnant women's group meeting at least 3 times; and

3. The woman must be from 29 VDCs of Makwanpur where PWG meetings were held at least one year back.

For the non-exposed group:

1. A recently delivered woman who delivered live or still births in the last one year who was not a member of pregnant women group during the last pregnancy;

2. The woman, who had never participated in the pregnant women group meeting; and

3. The woman must be from 29 VDCs of Makwanpur.

Data Collection Technique / Methods

The data collection techniques were personal interviews of the target mothers with structural questionnaire for the quantitative data collection and focus group discussions (FGD) with FCHVs for qualitative data collection. The quantitative data collection was done as follows:

- Coordinated with District Health Office and the concerned health facilities to share about data collection and the objective of the study.

- Prepared a work plan for the data collection and coordinated with FCHVs and confirmed the number of women, who had delivered less than a year back and verified with PWG register and also orally with members' of PWG whether they were PWG members or not.

- Data were collected from door to door visit and also in an EPI session and an Out Reach Clinic.

- The informed verbal consent as per Nepal Health Research Council's (NHRC) guideline was taken from each respondent.

- Rapport building and privacy was maintained during the interview.

- The utilization of $\mathrm{MNCH}$ services of mothers, who had delivered less than a year back were confirmed directly from a MCH register and an EPI register in the local health facility. 
A Pregnant Women's Group: Page31

- The filled up questionnaire was reviewed on the spot before leaving the place by an enumerator and then second review was done in the room by a next enumerator.

- Confirmed that the numbers of PWG member's data collection were equal to non-PWG members in a Ward (Village). If not, we collected the data for the non-PWG member from nearest ward to make equal sample.

- After returning from the field, the questionnaires were reviewed again and put the record numbers.

\section{$\underline{\text { Statistical method and level of significance }}$}

Statistical package for the social sciences (SPSS) version 20 was used for the data analysis and the level of significant was $95 \%$ confidence level.

\section{Ethical approval}

This study proposal was approved by Nepal Health Research Council Ethical Review Board on 01 April 2015 (2072 - 12 - 18) with registration number 10/2015, approval letter ref. No. 1808 dated 06 April 2015.

\section{RESULTS}

The increase in the utilization of $\mathrm{MNCH}$ care services were statistically significant among women who were PWG members during their last pregnancy than who were not as shown in the Table \# 1 , though the average age, educational status, child parity, ethnicity, disadvantaged proportion, geographical location and health facility are not difference between PWG and non-PWG respondents.

Table\# 1: Comparison of MNCH health care services among PWG and non-PWG

\begin{tabular}{|l|l|l|l|l|l|l|}
\hline $\begin{array}{l}\text { MNCH care services utilized } \\
\text { in the last pregnancy by } \\
\text { recently delivered women }\end{array}$ & $\begin{array}{l}\text { PWG } \\
(\mathbf{n =} \\
\mathbf{4 2 3})\end{array}$ & $\begin{array}{l}\text { NPWG } \\
(\mathbf{n =} \\
\mathbf{4 2 3})\end{array}$ & $\begin{array}{l}\text { relative } \\
\text { risk } \\
(\mathbf{R R})\end{array}$ & $\begin{array}{l}\mathbf{9 5 \%} \\
\text { Confidence } \\
\text { interval } \\
(\mathbf{C I})\end{array}$ & $\begin{array}{l}\text { Attributable } \\
\text { risk (AR) }\end{array}$ & P value \\
\hline 4+Antenatal care visits & $96.2 \%$ & $57.5 \%$ & 1.7 & $1.5-1.8$ & $40.3 \%$ & $<0.0001$ \\
\hline 2+Tetanus Toxoid vaccine & $100.0 \%$ & $88.4 \%$ & 1.1 & $1.1-1.2$ & $11.6 \%$ & $<0.0001$ \\
\hline $\begin{array}{l}\text { Iron/folic acid started at 4- } \\
\text { month }\end{array}$ & $98.1 \%$ & $66.2 \%$ & 1.5 & $1.4-1.6$ & $32.5 \%$ & $<0.0001$ \\
\hline Iron/folic acid for 6-months & $97.4 \%$ & $61.0 \%$ & 1.6 & $1.5-1.7$ & $37.4 \%$ & $<0.0001$ \\
\hline Deworming and & $99.8 \%$ & $83.9 \%$ & 1.2 & $1.1-1.2$ & $15.9 \%$ & $<0.0001$ \\
\hline $\begin{array}{l}\text { Birth Preparedness (money, } \\
\text { blood } \\
\text { transportation) }\end{array}$ & $67.0 \%$ & $8.0 \%$ & 8.3 & $5.2-13.3$ & $88.0 \%$ & $<0.0001$ \\
\hline Institutional delivery & $74.2 \%$ & $58.6 \%$ & 1.3 & $1.1-1.4$ & $21.0 \%$ & $<0.0001$ \\
\hline SBA delivery & $75.9 \%$ & $58.6 \%$ & 1.3 & $1.2-1.4$ & $22.7 \%$ & $<0.0001$ \\
\hline
\end{tabular}

Vol. 3. No. I

www.phdcentre.edu.np 
ISSN: 2362-1303 (Paper) | elSSN: 2362-1311(Online)

JOURNAL OF ADVANCED ACADEMIC RESEARCH (JAAR)

Jan 2016

A Pregnant Women's Group: Page32

\begin{tabular}{|l|l|l|l|l|l|l|} 
3+postnatal check-up & $9.2 \%$ & $4.0 \%$ & 2.3 & $1.3-4.0$ & $56.4 \%$ & $<0.0001$ \\
\hline Postnatal vitamin-A & $98.6 \%$ & $79.7 \%$ & 1.2 & $1.2-1.3$ & $19.2 \%$ & $<0.0001$ \\
\hline $\begin{array}{l}\text { All 5-essential newborn cares as } \\
\text { mentioned below }\end{array}$ & $24.8 \%$ & $7.1 \%$ & 3.5 & $2.3-5.1$ & $71.4 \%$ & $<0.0001$ \\
\hline $\begin{array}{l}\text { 1. Wiped the newborn with } \\
\text { clean, dry and soft cloth }\end{array}$ & $96.0 \%$ & $75.7 \%$ & 1.2 & $1.1-1.3$ & $21.2 \%$ & $<0.0001$ \\
\hline $\begin{array}{l}\text { 2. Kept the newborn on } \\
\text { mother's chest (Kangaroo } \\
\text { mother care) }\end{array}$ & $81.8 \%$ & $44.6 \%$ & 1.8 & $1.6-2.0$ & $45.4 \%$ & $<0.0001$ \\
\hline $\begin{array}{l}\text { 3. Breastfed within one hour of } \\
\text { birth }\end{array}$ & $90.5 \%$ & $53.9 \%$ & 1.6 & $1.5-1.8$ & $40.5 \%$ & $<0.0001$ \\
\hline $\begin{array}{l}\text { 4. Nothing applied, kept clean } \\
\text { and dry the umbilicus stump }\end{array}$ & $46.3 \%$ & $21.5 \%$ & 2.1 & $1.7-2.6$ & $53.6 \%$ & $<0.0001$ \\
\hline $\begin{array}{l}\text { 5. Delayed bath after 24 hours } \\
\text { of birth }\end{array}$ & $58.9 \%$ & $25.5 \%$ & 2.3 & $1.9-2.7$ & $56.6 \%$ & $<0.0001$ \\
\hline $\begin{array}{l}\text { BCG vaccine as per mother's } \\
\text { recall }\end{array}$ & $91.9 \%$ & $91.4 \%$ & 1.0 & $1.0-1.0$ & $1.0 \%$ & $<0.0001$ \\
\hline BCG vaccine scar & $77.3 \%$ & $70.8 \%$ & 1.1 & $1.0-1.2$ & $8.4 \%$ & $<0.0001$ \\
\hline Birth registration of infant & $28.4 \%$ & $18.5 \%$ & 1.5 & $1.2-2.0$ & $34.9 \%$ & $<0.0001$ \\
\hline
\end{tabular}

DISCUSSION

Women group meta-analysis in 2013 showed that with the participation of at least a third of pregnant women and population coverage of 450-750 per group, women's groups practicing participatory learning and action were a cost-effective strategy to improve maternal and neonatal survival in resourcepoor settings. Their implementation in rural areas of Countdown countries could save many lives. In these settings, policy makers should consider women's groups as a core strategy to complement efforts made to improve safer motherhood and newborn care through better midwifery and obstetric care.

Findings indicated that four time antenatal care visits was $96.2 \%$ in the member of PWG group and only $75.5 \%$ in non-PWG with relative risk of 1.7 (1.5-1.8). Similar result was found by Manandar et.al. 2004 in the Makwanpur Women group study in Nepal which also showed any ANC visit of 55\% in intervention and $30 \%$ in control clusters with odd ratio of 2.8 (1.4 - 5.6). The study in Malawi (Lewycka et. al., 2013) also showed that increased uptake of any antenatal care was significant difference $(\mathrm{p}<0 \cdot 05)$ between intervention and control groups in published data.

Iron/folic acid supplement for 6-months during pregnancy was 97.4\% in PWG and $61 \%$ in NPWG with relative risk of $1.6(1.5-1.7)$. Similar result was found in the Makwanpur Women group study in 2009 which showed any iron and folic acid supplement was $49 \%$ in intervention and $27 \%$ in control clusters with odd ratio of $2.0(1.1-3.5)$.

Institutional delivery was $74.2 \%$ in PWG and 58.6\% in NPWG with relative risk of $1.3(1.1$ 1.4). Similar result was found in the Makwanpur Women group study in 2009 which showed Institutional delivery was $7 \%$ in intervention and $2 \%$ in control clusters with odd ratio of 3.6 (1.6 - 8.1).

Vol. 3. No. I

www.phdcentre.edu.np 
A Pregnant Women's Group: Page33

Newborn breastfed within one hour of birth was $90.5 \%$ in PWG and 53.9\% in NPWG with relative risk of $1.6(1.5-1.8)$. The study in Bangladesh (Fottrell et al, 2013) also showed that increased early initiation of breastfeeding (within one hour of birth) was significantly different $(p<0 \cdot 05)$ between intervention and control groups in published data.

The proportions of the respondents of disadvantaged group in this study were $81.8 \%$. The data was not analyzed separately only for the disadvantaged group. There was $18.2 \%$ mix of other respondents with the disadvantaged group.

The comparison of the four Women's Group interventions is shown in Table \#2.

Table\# 2: Comparison of the four Women's Group interventions

\begin{tabular}{|c|c|c|c|c|}
\hline Interventions & $\begin{array}{l}\text { 1. The MIRA } \\
\text { Makwanpur } \\
\text { Study Nepal (1999 } \\
\text { - 2009) }\end{array}$ & $\begin{array}{l}\text { 2. Women's Groups } \\
\text { of Bangladesh, } \\
\text { India, Malawi, and } \\
\text { Nepal. }\end{array}$ & $\begin{array}{lr}\text { 3. The } & \text { Effect of } \\
\text { Scaling } & \text { up } \\
\text { Women's } & \text { Groups } \\
\text { on } & \text { Birth } \\
\text { Outcomes r in } \\
\text { Bangladesh Study }\end{array}$ & $\begin{array}{l}\text { 4. The Bara } \\
\text { Pregnant Women } \\
\text { Group (PWG) } \\
\text { Impact Study in } \\
\text { Nepal }\end{array}$ \\
\hline References & $\begin{array}{l}\text { Manandhar D S et } \\
\text { al. } 2004\end{array}$ & Prost A et al.2013 & Azad K et al. 2010 & $\begin{array}{l}\text { Maskey M K et al. } \\
2011\end{array}$ \\
\hline $\begin{array}{l}\text { Research } \\
\text { design }\end{array}$ & $\begin{array}{ll}\text { Cluster } & \\
\text { Randomized } & \\
\text { Controlled } & \text { Trial } \\
\text { (RCT) } & \end{array}$ & $\begin{array}{l}\text { A systematic review } \\
\text { and meta-analysis of } \\
\text { RCTs }\end{array}$ & RCT & 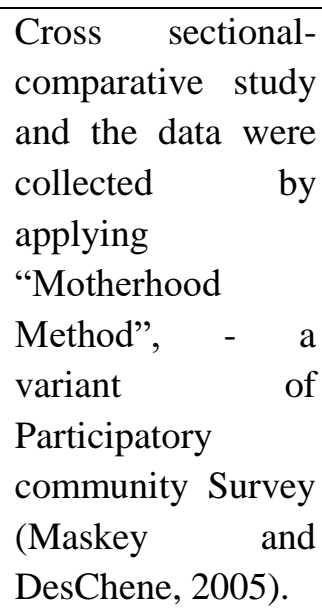 \\
\hline Target group & Women's groups & Women's groups & Women's groups & $\begin{array}{ll}\text { Pregnant } & \text { Women } \\
\text { Group } & \end{array}$ \\
\hline $\begin{array}{l}\text { Health } \\
\text { education } \\
\text { methods }\end{array}$ & $\begin{array}{l}\text { Participatory } \\
\text { learning rather than } \\
\text { instruction }\end{array}$ & $\begin{array}{l}\text { Participatory } \\
\text { learning and action }\end{array}$ & $\begin{array}{l}\text { Participatory action } \\
\text { and learning for } \\
\text { women }\end{array}$ & \begin{tabular}{lr}
\multicolumn{2}{l}{ Participatory action } \\
and & learning \\
including & pregnant \\
women & self- \\
monitoring & of \\
utilization & MNH \\
services &
\end{tabular} \\
\hline Impact & Intervention group & A $37 \%$ reduction in & Cluster-level mean & The study \\
\hline
\end{tabular}

Vol. 3. No. I

www.phdcentre.edu.np 
ISSN: 2362-1303 (Paper) | elSSN: 2362-1311(Online)

JOURNAL OF ADVANCED ACADEMIC RESEARCH (JAAR)

A Pregnant Women's Group: Page34

\begin{tabular}{|c|c|c|c|c|}
\hline $\begin{array}{l}\text { maternal and } \\
\text { neonatal } \\
\text { deaths }\end{array}$ & $\begin{array}{l}\text { was nearly } 30 \% \\
\text { lower than in the } \\
\text { control group. } \\
\text { Hierarchical } \\
\text { modeling-taking } \\
\text { clustering into } \\
\text { account-yielded } \\
\text { an odds ratio of } \\
0.70 \text { (95\% CI } \\
0.53 \text { - } 0.94) \text { for } \\
\text { neonatal mortality } \\
\text { in the intervention } \\
\text { clusters compared } \\
\text { with the control } \\
\text { clusters. }\end{array}$ & $\begin{array}{l}\text { maternal mortality } \\
\text { (odds ratio } 0.63, \\
95 \% \text { CI } 0.32-0.94) \\
\text { and a } 23 \% \text { reduction } \\
\text { in neonatal mortality } \\
(0.77,0.65-0.90) \text {. } \\
\text { A subgroup analysis } \\
\text { of the four studies in } \\
\text { which at least } 30 \% \\
\text { of pregnant women } \\
\text { participated in } \\
\text { groups showed a } \\
55 \% \text { reduction in } \\
\text { maternal mortality } \\
(0.45,0.17-0.73 \text { ) } \\
\text { and a } 33 \% \text { reduction } \\
\text { in neonatal mortality } \\
(0.67,0.59-0.74) \text {. }\end{array}$ & $\begin{array}{l}\text { NMR (adjusted for } \\
\text { stratification and } \\
\text { clustering) was } \\
33.9 \text { deaths per } \\
1000 \text { live births in } \\
\text { the intervention } \\
\text { clusters compared } \\
\text { with } 36.5 \text { per } 1000 \\
\text { in the control } \\
\text { clusters (risk ratio } \\
0.93 \text {, 95\% CI } \\
0.80-1 \cdot 09 \text { ). }\end{array}$ & $\begin{array}{l}\text { demonstrated with } \\
\text { high precision that } \\
\text { PWG members } \\
\text { have reduced risk } \\
\text { (about } 50 \% \text { less) of } \\
\text { dying during } \\
\text { pregnancy, } \\
\text { childbirth and } \\
\text { puerperium as } \\
\text { compared to the } \\
\text { non-PWG } \\
\text { members. Their } \\
\text { children also have } \\
\text { similar lower risk } \\
\text { of dying during } \\
\text { perinatal and } \\
\text { infancy periods. }\end{array}$ \\
\hline Drawbacks & $\begin{array}{l}\text { Fewer \% of } \\
\text { pregnant women } \\
\text { have participated in } \\
\text { the Women } \\
\text { Groups. }\end{array}$ & $\begin{array}{l}\text { Fewer \% of pregnant } \\
\text { women have } \\
\text { participated in the } \\
\text { Women Groups. }\end{array}$ & $\begin{array}{l}\text { Fewer \% of } \\
\text { pregnant women } \\
\text { have participated in } \\
\text { the Women } \\
\text { Groups. }\end{array}$ & $\begin{array}{l}90 \% \text { pregnant } \\
\text { women and } 10 \% \\
\text { postnatal mothers }\end{array}$ \\
\hline Interpretation & $\begin{array}{l}\text { Women groups } \\
\text { with participatory } \\
\text { teaching learning } \\
\text { processes help to } \\
\text { reduce neonatal } \\
\text { rate in Makwanpur } \\
\text { Nepal }\end{array}$ & $\begin{array}{l}\text { With the } \\
\text { participation of at } \\
\text { least a third of } \\
\text { pregnant women and } \\
\text { adequate population } \\
\text { coverage, women's } \\
\text { groups practicing } \\
\text { participatory } \\
\text { learning and action } \\
\text { are a cost-effective } \\
\text { strategy to improve } \\
\text { maternal and } \\
\text { neonatal survival in } \\
\text { low-resource } \\
\text { settings. }\end{array}$ & $\begin{array}{l}\text { For participatory } \\
\text { women's groups to } \\
\text { have a significant } \\
\text { effect on neonatal } \\
\text { mortality in rural } \\
\text { Bangladesh, } \\
\text { detailed attention } \\
\text { to programme } \\
\text { design and } \\
\text { contextual factors, } \\
\text { enhanced } \\
\text { population } \\
\text { coverage, and } \\
\text { increased } \\
\text { enrolment of newly } \\
\text { pregnant women } \\
\text { might be needed. }\end{array}$ & $\begin{array}{l}\text { The pregnant } \\
\text { women group - } \\
\text { participatory } \\
\text { teaching learning } \\
\text { with self- } \\
\text { monitoring } \\
\text { increase use of } \\
\text { MNH care services } \\
\text { and to reduce the } \\
\text { maternal and } \\
\text { newborn deaths in } \\
\text { developing } \\
\text { countries like } \\
\text { Nepal. }\end{array}$ \\
\hline Conclusion & \multicolumn{4}{|c|}{$\begin{array}{l}\text { The participatory teaching learning and action methods with pregnant women self- } \\
\text { monitoring of behavioural mapping of maternal and newborn health }(\mathrm{MNH}) \text { services is }\end{array}$} \\
\hline
\end{tabular}

Vol. 3. No. I

www.phdcentre.edu.np 


\begin{tabular}{|l|l|}
\hline $\begin{array}{l}\text { an effective intervention to change behaviour of the disadvantage community to } \\
\text { increase MNH services and reduce maternal and newborn deaths at low resource setting } \\
\text { at developing countries like Nepal. }\end{array}$ \\
\hline
\end{tabular}

\section{CONCLUSIONS}

The study showed that use of maternal, newborn and child health $(\mathrm{MNCH})$ care services were increased significantly among women who were the PWG members during their last pregnancy than who were not, though the average age, educational status, child parity, ethnicity, disadvantaged proportion, geographical location and health facility are constant between PWG and non-PWG respondents. A pregnant women group approach increases the utilization of $\mathrm{MNCH}$ care services in disadvantaged and scattered community in Nepal.

The strengths of the survey methods were random selection of the respondents, same questionnaire was used for both PWG member and non-member, and the confounding variables (like age, education, ethnicity and geographical location) were minimized and no statistical difference between PWG members and non-members. The sample size was derived from standard formula for generalization and equal sample size in both groups. This study measured process indicators of maternal, newborn and child health like antenatal care visit etc. However, it did not measure impact of study like maternal, newborn and child mortalities. The proportions of the respondents of disadvantaged group in this study were $81.8 \%$ (in PWG $83.0 \%$ and non PWG 80.6\%). The data was not analyzed separately only for the disadvantaged group. There was mix of $18.2 \%$ other respondents with the disadvantaged group.

The pregnant women group approach should be replicated in the disadvantaged community where $\mathrm{MNCH}$ health care services coverage is low. The following points are recommended

- Repeated monthly participatory teaching learning on key maternal, newborn and child health $(\mathrm{MNCH})$ care services messages (like danger signs during the pregnancy, at birth and after birth, and danger signs for newborn) directly to a Pregnant Women Group (PWG);

- Pregnant women self-monitoring of the utilization of the MNCH care services by using a behavioural mapping during the PWG meeting; and

- Scaling up the PWG in disadvantaged community where MNCH care services coverage is low.

\section{REFERENCES}

Audrey Prost, Tim Colbourn, Nadine Seward and et al. (2013). Women's groups practising participatory learning and action to improve maternal and newborn health in low-resource settings: a systematic review and meta-analysis. Lancet 2013; 381: 1736-46

Baral, KP. (2006). Concept and approach of pregnant women's group: An approach to increase coverage of maternal health services in rural Nepal, Kathmandu: Nepal.

Dipty Nawal, TV Sekhar, Srinivas Goli. (2013). Decomposing the socioeconomic inequality in utilisation of maternal health-care services in selected Asian and sub-Saharan African countries. Lancet 2013; 381: special issue, S97.

District Health Office Makwanpur (2012). Annual Report 2070-71

Vol. 3. No. I

www.phdcentre.edu.np 
ISSN: 2362-1303 (Paper) | elSSN: 2362-1311(Online)

JOURNAL OF ADVANCED ACADEMIC RESEARCH (JAAR)

A Pregnant Women's Group: Page36

Fottrell E, Azad K, Kuddus A, Younes L, Shaha S, Nahar T.(2013). The eff ect of increased coverage of participatory women's groups on neonatal mortality in Bangladesh: a cluster-randomised trial. JAMA Pediatric 2013 Sep; 167(9):816-25.

Lewycka S, Mwansambo C, Rosato M, et al.(2013). Eff ect of women's groups and volunteer peer counselling on rates of mortality, morbidity, and health behaviours in mothers and children in rural Malawi (MaiMwana): a factorial, cluster randomised controlled trial. Lancet 2013; 381: 1721-35.

http://www.who.int/woman_child_accountability/ierg/reports/30a_Womens_groups_metaanalysis .pdf)

Manandhar DS, Osrin D, Shrestha BP, et al, members of the MIRA Makwanpur trial team.(2004) Effect of a participatory intervention with womens groups on birth outcomes in Nepal: cluster randomized controlled trial. Lancet 2004; 364: 970-79.

Maskey M.K, Baral K.P., Shah R, Shrestha BD, Janet L. \& Kenneth J. R. (2011). Field test results of the motherhood method to measure maternal mortality. Indian J Med Res 133, January 2011, pp 6469

Ministry of Health and Population (MOHP) [Nepal], New Era, and ICF International INC. (2012). Nepal Demographic Health Survey 2011. Kathmandu, Nepal: Ministry of Health and Population, New ERA, and ICF International, Calverton, Maryland.

Shrestha B.D. Pregnant Women's Groups and the Impact on Newborn's Mortalities in Bara District, Nepal. (2009). Nepal Public Health Association (NEPHA) Newsletter, Volume \#1, Issue \# 2, Pg 8, November 2009

UNICEF (2015), Levels \& Trends in Child Mortality Report 2015 Estimates Developed by the UN Interagency Group forChild Mortality Estimation.

WHO (2015), Trends in maternal mortality: 1990 to 2015: estimates by WHO, UNICEF, UNFPA, World Bank Group and the United Nations Population Division. 